\title{
A Scale for Measuring Teachers' Mathematics-Related Beliefs: A Validity and Reliability Study
}

\section{Yoppy Wahyu Purnomo}

Dr., Faculty of Teacher Training and Education, University of Muhammadiyah Prof. Dr.

HAMKA, Jakarta, Indonesia, yoppy.w.purnomo@uhamka.ac.id

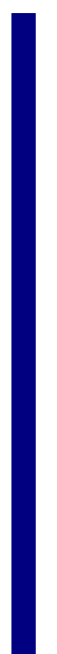

The purpose of this study was to develop and validate a scale of teacher beliefs related to mathematics, namely, beliefs about the nature of mathematics, mathematics teaching, and assessment in mathematics learning. A scale development study was used to achieve it. The draft scale consisted of 54 items in which 16 items related to beliefs about the nature of mathematics, 23 items related to beliefs about the teaching of mathematics, and 15 items related to beliefs about assessment in mathematics learning. At the first phase, 252 primary school teachers participated and exploratory factor analysis (EFA) was performed to evaluate the structure of the scale factor. There were two factors at each scale resulted from the analysis. At the second phase, 350 primary school teachers participated and confirmatory factor analysis (CFA) was performed to confirm the factors resulted from the EFA. The result of CFA indicated that the established model had sufficient fit indices. In addition, each factor had an adequate internal consistency coefficient, which was in the range of $0.715-0.787$. Thus, this scale could be a satisfactory tool to assess teachers' mathematics-related beliefs. Subsequent studies could combine these three scales into an integrated scale, to simplify statistical analysis.

Key Words: mathematics-related beliefs, primary school teachers, scale development, validation studies

\section{INTRODUCTION}

Several researchers were in common agreement that practices and behaviors of teachers in classrooms could be attributed to their own beliefs (Purnomo, Suryadi, \& Darwis, 2016; Wilkins, 2008). Purnomo et al. (2016) found that pre-service teachers who hold belief that mathematics is a subject that has relevance to context and environment of students, they could make effort to present mathematical content in such a way that could be imagined by their students. In contrast, teachers who hold beliefs that solving mathematical problems must be in accordance with fixed rules and procedures tend to emphasize their practices on it. This type of practices is mostly known as instrumental

Citation: Purnomo, Y. W. (2017). A Scale for Measuring Teachers' Mathematics-Related Beliefs: A Validity and Reliability Study. International Journal of Instruction, 10(2), 23-38. https://doi.org/10.12973/iji.2017.1022a 
teaching which might impede students to learn mathematics meaningfully as it heavily focuses on developing procedural knowledge devoid of understanding. As a result, students often make error when mathematical procedure is not fulfilled (Purnomo, Kowiyah, Alyani, \& Assiti, 2014). Therefore, it makes sense that the focus of teacher education programs is to build teachers' belief systems (Jao, 2016; Shinde \& Karekatti, 2012), especially to improve mathematics learning process.

In recent decades, there has been concern about studies regarding building beliefs and development of mathematical knowledge for teaching (e.g. Lui \& Bonner, 2016; Tatto et al., 2008). Drageset (2010) and Holm and Kajander (2012) revealed that beliefs and the knowledge are related to and influenced each other in teacher professional development. It might affect quality of teaching and subsequently impact on students achievement in mathematics learning (Kajander, 2007).

Exploring teachers' belief is important step for developing policies and or obtaining an effective approach in teacher education programs. In Indonesia, teacher education programs has not focused on building teachers' belief systems related to mathematics (Purnomo et al., 2016). In addition, research examining teachers' belief systems related to mathematics in Indonesia is yet to be conducted. Thus, the study focus on developing instruments to assess teachers' belief systems related to mathematics in Indonesia.

Some studies demonstrate different opinions about the most appropriate method to assess teachers' beliefs in mathematics. Leder and Forgasz (2002) summarize some of the methods that can be used such as interviews, questionnaires, observation, analysis of journal entries, reflections, and post-lesson conferences. In mathematics education research, a clinical interview is common method to explore teacher beliefs. However, this method is limited to a small sample, so it is poor in describing tendency of mathematics-related beliefs that are held by teachers on a large scale. Thus, questionnaires have become one of the major instruments appropriate to describe the mathematics-related beliefs of teachers on a large scale.

There were several studies conducted to develop a scale of teacher beliefs, such as Brown and colleagues (Brown, Hui, Yu, \& Kennedy, 2011; Brown \& Remesal, 2012), who developed a scale of teacher beliefs about assessment. In addition, Barkatsas and Malone (2005) developed a scale of beliefs about nature, teaching and learning mathematics for secondary school teachers. However, studies of exploring teachers' beliefs about the nature of mathematics, teaching and learning, and assessment in an integrated manner are still limited. Therefore, this study aims to develop a scale for assessing teacher beliefs related to mathematics, which consists of beliefs about the nature of mathematics, teaching of mathematics, and assessment in mathematics learning. Our scale could be used to describe the mathematics-related beliefs of teachers on a large scale.

\section{CONTEXT AND LITERATURE REVIEW}

Arbitrary construct of beliefs has led many researchers to define and draw conclusions differently (Purnomo et al., 2016; Savion, 2009). Some researchers (e.g. Furinghetti \& Pehkonen, 2002; Purnomo et al., 2016) agree that belief can be in the cognitive domain 
if we view relationship between beliefs and knowledge. On the other hand, when we view beliefs as a reaction to a particular situation, we assume that beliefs are associated to affective domain of an individual. In this context, knowledge can be categorized into objective knowledge and subjective knowledge (Ernest, 1991; Furinghetti \& Pehkonen, 2002). Objective knowledge is knowledge that is accepted by certain community, while subjective knowledge is knowledge that is created or interpreted by individuals and does not have to be evaluated by others. Therefore, beliefs could be explained as subjective knowledge of an individual based on his/her experience and expressed with propositional attitudes, views and perceptions for the value of truth (Purnomo et al., 2016).

Teachers' beliefs related to mathematics encompass their beliefs about the nature of mathematics, mathematics teaching (and learning), and assessment. Beliefs about the nature of mathematics comprise an individual's subjective knowledge of mathematics as a discipline (Beswick, 2012; Thompson, 1992), so this belief is related to an individual's perspective of the philosophy of mathematics. Meanwhile, teacher beliefs about teaching mathematics comprise the teacher's subjective knowledge on the various types and steps of teaching, meaning teaching and learning, the role of teachers and students in learning, how students learn mathematics, and classroom activities related to the teaching of mathematics (Boz, 2008; Thompson, 1992). The implication is that teacher beliefs about learning become an integral part and a subset of beliefs about teaching. According to Purnomo et al. (2016), teacher beliefs about learning are always explicitly linked with how to make students learn the best. Therefore, we only use the term "teaching" for the case of teacher beliefs. Finally, beliefs about assessment refer to the subjective knowledge of teachers regarding the nature, essence, and/or purpose of assessment in mathematics learning (Brown \& Gao, 2015; Suci \& Purnomo, 2016).

We use another aspect as a basis to develop a scale of teacher beliefs related to mathematics. They are interdependent and have their respective positions in guiding the direction and purpose of the teacher in mathematics classes. For example, for teachers who believe that mathematics is static or has absolute truth (that includes a set of rules, facts, or procedures used to obtain a correct answer), their belief in teaching leads to a transmission model of teaching that is characterized by exposure, drills, and memorization, known as instrumental teaching. As a result, assessment is more likely to be seen as a way to give punishment and verification.

\section{METHOD}

A scale development study was selected to develop an instrument that adequately measures the teachers' mathematics-related beliefs. The procedures were as follows (a) defining and specifying the construct being measured, (b) generating an item pool, (c) providing and considering the study of experts on initial item pool, (d) refining and validating scale, (e) evaluating the items (DeVellis, 2017; Wymer \& Alves, 2013). Furthermore, explanation related to participants, instrument and procedures, and data analysis can be seen in detail below. 


\section{Participant}

The population of the research is primary school teachers in Jakarta in the 2015/2016 academic year. The participants in this research were divided into two independent samples. The participants in the first sample consist of 252 primary school teachers in Jakarta, who were selected conveniently. This technique has been selected for some benefits, including less cost and time-consuming, and ease of administration (McMillan \& Schumacher, 2006). They are $19.8 \%$ male and $79.4 \%$ female, while the rest had no information. The participants in the second sample consist of 350 teachers from 75 different primary schools in East Jakarta. Initially, out of six cities in Jakarta, one city was selected conveniently. Then schools in the city were selected randomly. From those schools, several teachers were picked up conveniently as participants. They are $80.9 \%$ female and $17.5 \%$ are male, while $1.5 \%$ had no information. The sample size for both groups was more than the acceptable threshold for factor analysis which was equal to 200 (Barrett, 2007; Pituch \& Stevens, 2016).

\section{Instrument and Procedures}

Studies related to beliefs (i.e. Beswick, 2005; Brown, 2004; Charalambous, Philippou, \& Kyriakides, 2002; Genc, 2005; Op't Eynde \& De Corte, 2003; Tatto et al., 2008; Van Zoest, Jones, \& Thornton, 1994) are used to develop the questionnaire items. The questionnaire was classified into four parts: questions about teacher demographics, beliefs about the nature of mathematics (BN-M), beliefs about the teaching of mathematics (BT-M), and beliefs about assessment in mathematics learning (BA-M). The draft scale includes 54 items using six-point Likert scales ranging from 1 (strongly disagree) to 6 (strongly agree). The draft scale was written in Bahasa Indonesia. The composition of each subscale consists of 16 items BN-M, 23 items BT-M, and 15 items BA-M. After preparing the questionnaire items, the content validity was qualitatively performed with the involvement of two experts hold doctorates in the field of mathematics education and one expert hold doctorates in the field of educational research and evaluation. Two experienced teachers were also involved in this research. Analysis and revisions were performed based on advice from experts.

\section{Data Analysis}

Analysis of the data of BN-M, BT-M, and BA-M was conducted separately. This allowed researchers to classify indicators into the respective appropriate dimensions. In addition, it can also be used for further research interests related to the consistency between them. The data obtained from the first group were analyzed using Exploratory Factor Analysis (EFA) aided IBM SPSS statistical software version 21. The EFA procedure uses principal components analysis (PCA) and two common methods: varimax and promax. Both are compared to obtain the best possible result. To determine the number of factors, we look at the Kaiser criteria, screening plot, and interpretation of each factor. The construct was developed from the first group of data, further confirmed using Confirmatory Factor Analysis (CFA) with the help of statistical software SPSS AMOS version 22. The Maximum Likelihood (ML) method with Bollen-Stine bootstrapping with 500 samples and bias-corrected bootstrap confidence intervals at 
90\% was employed as an alternative for data that violate the assumption of normal (Byrne, 2013; Nevitt \& Hancock, 2001). Fit indices for the model using several statistical criteria with a threshold in each are shown in Table 1, i.e. Normed Chi-Square (NC), Root Mean Square Error of Approximation (RMSEA), Standardized Root Mean Square Residual (SRMR), Goodness-of-Fit Statistic (GFI), Adjusted Goodness-of-Fit Statistic (AGFI), Normed Fit Index (NFI), Tucker-Lewis Index (TLI), and the Comparative Fit Index (CFI).

Table 1

Threshold measures for fit indices model

\begin{tabular}{lcc}
\hline Index & \multicolumn{2}{c}{ Threshold } \\
\cline { 2 - 3 } & Good Fit & Acceptable fit \\
\hline NC & $1 \leq N C \leq 2$ & $2 \leq N C \leq 3$ \\
\hline RMSEA & $\leq 0.05$ & $0.05<$ RMSEA $\leq 0.08$ \\
\hline SRMR & $\leq 0.05$ & $0.05<$ SRMR $\leq 0.08$ \\
\hline GFI & $\geq 0.95$ & $\geq 0.90$ \\
\hline AGFI & $\geq 0.95$ & $\geq 0.90$ \\
\hline NFI & $\geq 0.95$ & $\geq 0.90$ \\
\hline CFI & $\geq 0.95$ & $\geq 0.90$ \\
\hline TLI & $\geq 0.95$ & $\geq 0.90$ \\
\hline
\end{tabular}

Furthermore, the construct validity (i.e. convergent and discriminant validity) was examined. This can be evaluated by how well the coefficients of standardized factor loading, composite reliability (CR) and average variance extracted (AVE) are generated. A coefficient of 0.4 for standardized factor loading, 0.7 for CR, and 0.5 for AVE is an adequate limit for each of these measures. The discriminant validity can be evaluated by comparing the square root of AVE for any two constructs and the correlation estimate between the same construct (Abdullah, Marzbali, Woolley, Bahauddin, \& Tilaki, 2014; Hair, Black, Babin, \& Anderson, 2010). In addition, Hair et al. (2010) state that discriminant validity can also be evaluated by comparing AVE with the maximum shared squared variances (MSV) and the average squared shared variances (ASV). Finally, the internal consistency of each dimension for each subscale of beliefs is calculated using Cronbach's alpha. A coefficient of 0.6 is used as the limit for adequate internal consistency (Clark \& Watson, 1995).

\section{FINDINGS}

\section{Data Screening}

Prior to the EFA and CFA, data screening was performed by checking the missing data, the normality of the data, and outliers. Multiple imputation methods is a recommended way to cope with missing data (Fichman \& Cummings, 2003; Schlomer, Bauman, \& Card, 2010). Furthermore, transformation was selected to normalize the data. Data for EFA met the criteria of normal, while for the data for the CFA, only the scale of BN-M is normally distributed. Therefore, for the data is not normal: it will be reported with the p-value from Bollen-Stine bootstrapping (Byrne, 2013; Loehlin, 2004). 
Analysis of the matrix correlation for each dimension (i.e. BN-M, BT-M, and BA-M) was performed with the Kaiser-Meyer-Olkin (KMO) measure of sampling adequacy; the results were 0.693, 0.822, and 0.903 respectively. On the other hand, Bartlett's test of sphericity produces a p-value $<0.01$ for each subscale.

\section{Beliefs about the Nature of Mathematics}

\section{EFA of the BN-M}

An iterative process of PCA with a varimax method to construct BN-M produced two components or factors. The solution was calculated from $46.034 \%$ of the total variance, 10 of the 16 items were used to describe both factors. Each of the items had significant factor loading because it was in the range of $0.536-0.759$, i.e. above 0.32 (Tabachnick \& Fidell, 2007). We named each factor based on the relationship between items and the relevant literature (Ernest, 1991, 1998; Hersh, 1997; Op’t Eynde \& De Corte, 2003). Factor 1 was associated with the view of mathematics as relevant objects; factor 2 was associated with dynamic views about mathematics. However, both factors were equally related to a view of social constructivism in mathematics, so as to identify traditional beliefs about mathematics that can be measured by looking at the opposite of the two factors. Coefficient alpha internal consistency estimates for the two factors were 0.709 and 0.651 for relevant and dynamic factors respectively.

\section{CFA for $B N-M$}

CFA by the ML method was performed with model refinement twice, the output for the final model was $\chi^{2}=30.138 ; \mathrm{df}=24 ; \mathrm{p}=0.180 ; \mathrm{NC}=1.256$; $\mathrm{RMSEA}=0.028$; SRMR $=0.044 ;$ GFI $=0.978 ;$ AGFI $=0.960 ; \mathrm{NFI}=0.961 ; \mathrm{TLI}=0.988 ; \mathrm{CFI}=0.992$. The model fit was good. A summary of the analysis results is given in Table 2.

Table 2

Fit Indices and BN-M Model Comparison

\begin{tabular}{lccccc}
\hline & Good Fit & Acceptable Fit & Model 0 & Model 1 & Model 2 \\
\hline NC & $1 \leq N C \leq 2$ & $2 \leq N C \leq 3$ & 3.003 & 2.440 & 1.256 \\
\hline RMSEA & $\leq 0.05$ & $0.05<$ RMSEA $\leq 0.08$ & 0.079 & 0.067 & 0.028 \\
\hline SRMR & $\leq 0.05$ & $0.05<$ SRMR $\leq 0.08$ & 0.066 & 0.053 & 0.044 \\
\hline GFI & $\geq 0.95$ & $\geq 0.90$ & 0.936 & 0.954 & 0.978 \\
\hline AGFI & $\geq 0.95$ & $\geq 0.90$ & 0.897 & 0.921 & 0.960 \\
\hline NFI & $\geq 0.95$ & $\geq 0.90$ & 0.877 & 0.918 & 0.961 \\
\hline CFI & $\geq 0.95$ & $\geq 0.90$ & 0.985 & 0.950 & 0.988 \\
\hline TLI & $\geq 0.95$ & $\geq 0.90$ & & 0.949 & 0.992 \\
\hline
\end{tabular}

Note:

Model 1: Removal of item dynamic 1

Model 2: Pairs 99 and e10; 28 and e10; $e 8$ and e9; $e 6$ and e9; e6 and e8; 66 and 27 used as free parameters

\section{Construct validity of the $B N-M$}

The analysis was continued by assessing the construct validity. Standardized factor loading for each variable in the construct beliefs about the nature of mathematics is in 
the range $0.53-0.75$. The $\mathrm{CR}$ values for the two factors were 0.75 and 0.77 for dynamic and relevant factors respectively. Both values were greater than the recommended threshold value. The AVE value of 0.5 was gained by the dynamic factor, but the value gained less than satisfactory to the relevant factor, i.e. $0.36<0.5$ as the recommended threshold. Nevertheless, Malhotra and Dash (2011) state that the convergent validity was adequate though only based on CR. Based on the literature, it can be interpreted that the construct beliefs about the nature of mathematics have adequate convergent validity. The discriminant validity of each of the factors was also adequate, as indicated by the value of AVE being larger than the MSV and ASV.

\section{Reliability of $B N-M$}

The internal consistency of each factor is greater than the recommended coefficient of 0.6. The dynamic factor has an alpha coefficient of 0.749 and 0.787 for the relevant factors. The analysis was also performed by looking at the item-corrected item-total correlation (CITC) with the result that all the items were insufficient criterion items that were 0.3 or more.

\section{Belief about Teaching of Mathematics}

\section{EFA of $B T-M$}

An iterative process of PCA with varimax rotation method resulted in two factors. The solution was calculated from $38.654 \%$ of the total variance and 20 of the 23 items used to describe both factors. Each of the items had a significant factor loading. Naming each factor is based on the relationship between items and is associated with the relevant literature (Cooper, 1993; Jonassen, 1991; Purnomo et al., 2016). Factor 1 was associated with a relational view of mathematics teaching and factor 2 with an instrumental view. The alpha coefficient estimates of internal consistency were 0.844 and 0.767 for the relational and instrumental factors, respectively.

\section{CFA of BT-M}

CFA by the ML method with Bollen-Stine bootstrapping was performed with three-time improvement. The output obtained for the final model of $\chi^{2}(38)=65.687 ; \mathrm{p}=0.03$; $\mathrm{NC}=1.729 ;$ RMSEA $=0.048 ; \mathrm{SRMR}=0.045 ; \mathrm{GFI}=0.965 ; \mathrm{AGFI}=0.939 ; \mathrm{NFI}=$ $0.915 ; \mathrm{TLI}=0.945 ; \mathrm{CFI}=0.962$ indicated an acceptable model fit.

Table 3

Fit Indices and BTM Model Comparison

\begin{tabular}{lcccccc}
\hline & Good fit & Acceptable fit & Model 0 & Model 1 Model 2 & Model 3 \\
\hline NC & $1 \leq N C \leq 2$ & $2 \leq N C \leq 3$ & 2,611 & 2,575 & 2,024 & 1,729 \\
\hline RMSEA & $\leq 0.05$ & $0.05<$ RMSEA $\leq 0.08$ & 0.071 & 0.700 & 0.059 & 0.048 \\
\hline SRMR & $\leq 0.05$ & $0.05<$ SRMR $\leq 0.08$ & 0.074 & 0.062 & 0.058 & 0.045 \\
\hline GFI & $\geq 0.95$ & $\geq 0.90$ & 0.879 & 0.920 & 0.940 & 0.965 \\
\hline AGFI & $\geq 0.95$ & $\geq 0.90$ & 0.849 & 0.890 & 0.912 & 0.939 \\
\hline NFI & $\geq 0.95$ & $\geq 0.90$ & 0.707 & 0.813 & 0.858 & 0.915 \\
\hline CFI & $\geq 0.95$ & $\geq 0.90$ & 0.768 & 0.850 & 0.896 & 0.945 \\
\hline TLI & $\geq 0.95$ & $\geq 0.90$ & 0.793 & 0.875 & 0.919 & 0.962 \\
\hline
\end{tabular}


Note:

Model 1 : Removal of items relational 11, relational 12, relational 14, relational 23, relational 13 , and relational 17

Model 2 : Pairs e15 and e16; e10 and e13; e10 and e12; el and e13; el and e12 used free parameters

Model 3 : Removal of items relational 15, relational 16, and instrumental 4

Construct validity of $B T-M$

The final model has a standardized factor loading value of $0.472-0.709$, so it closes a sufficient criterion. A sufficient criterion is also obtained the CR with the instrumental factor of 0.77 and the relational factor of 0.71 . Based on these two criteria, each factor has adequate convergent validity while the AVE value $<0.5$. The discriminant validity was also adequate because the AVE value was greater than the values of MSV and ASV.

\section{Reliability of $B T-M$}

Analysis of each of the items showed that the coefficient of CITC (i.e. 0.373-0.584) exceeds the recommended criteria. The coefficient alpha estimates of internal consistency for the two factors were 0.715 and 0.761 for the instrumental and relational factors, respectively.

\section{Beliefs about Assessment in Mathematics Learning (BA-M)}

EFA of $B A-M$

The analysis was followed by PCA. There are two factors that had eigenvalues greater than one; two to three factors were recommended by the screen plot. The analysis was followed by establishing two factors that were rotated using the varimax and promax methods. Based on the results of each method of rotation, the varimax method generates many overlapping variables; whereas for promax, only one variable overlapped. Therefore, we used the promax method to set the number of factors and to remove one variable of overlapping (i.e. item 7) to perform the analysis. The solution was calculated from $50.166 \%$ of the total variance; 14 items that were used to describe both factors. Each of the items had a significant factor loading. We named each factor based on the relationships between the items that were associated with the relevant literature (Cooper, 1993; Jonassen, 1991; Pellegrino, Chudowsky, \& Glaser, 2001; Purnomo, 2015, 2016; Shepard, 2000). Factor 1 was related to a view of assessment as an integral part of mathematics learning (abbreviated to integrated) and factor 2 to the assessment view that is irrelevant with the learning of mathematics (abbreviated to isolated). The alpha coefficient estimates of internal consistency were 0.828 for the integrated factor and 0.743 for the isolated factor.

\section{CFA of $B A-M$}

CFA by the ML method with Bollen-Stine bootstrapping was carried out with two-time improvement; the outputs obtained for the final model were $\chi^{2}(27)=47.392 ; \mathrm{p}=$ $0.120 ; \mathrm{NC}=1.755 ; \mathrm{RMSEA}=0.049 ; \mathrm{SRMR}=0.037 ; \mathrm{GFI}=0.971 ; \mathrm{AGFI}=0.940 ; \mathrm{NFI}$ $=0.954 ; \mathrm{TLI}=0.966 ;$ and CFI $=0.979$. In other words, the index showed that the model had a good fit. A summary of the analysis is shown in Table 4. 
Table 4

Fit Indices and BA-M Model Comparison

\begin{tabular}{lccccc}
\hline & Good fit & Acceptable fit & Model 0 & Model 1 & Model 2 \\
\hline NC & $1 \leq N C \leq 2$ & $2 \leq N C \leq 3$ & 5,140 & 4,557 & 1,755 \\
\hline RMSEA & $\leq 0.05$ & $0.05<$ RMSEA $\leq 0.08$ & 0.114 & 0.106 & 0.049 \\
\hline SRMR & $\leq 0.05$ & $0.05<$ SRMR $\leq 0.08$ & 0.075 & 0.062 & 0.037 \\
\hline GFI & $\geq 0.95$ & $\geq 0.90$ & 0.853 & 0.916 & 0.971 \\
\hline AGFI & $\geq 0.95$ & $\geq 0.90$ & 0.796 & 0.865 & 0.940 \\
\hline NFI & $\geq 0.95$ & $\geq 0.90$ & 0.768 & 0.850 & 0.954 \\
\hline CFI & $\geq 0.95$ & $\geq 0.90$ & 0.763 & 0.838 & 0.966 \\
\hline TLI & $\geq 0.95$ & $\geq 0.90$ & 0.802 & 0.878 & 0.979 \\
\hline
\end{tabular}

Note:

Model 1: removal items isolated15, integrated 9 , integrated6, and integrated2

Model 2: pairs el3 and e9; $e 5$ and e3; $e 10$ and e9; $e 3$ and e1; $e 11$ and e12; e5 and el used free parameters

\section{Construct Validity of the BA-M}

Based on the values of standardized factor loading that were in the range of 0.532 0.792 , each variable had an adequate factor loading. The CR values of the integrated and isolated factors were above the recommended threshold: 0.82 and 0.80 , respectively. This indicated that convergent validity was quite adequate, although the AVE coefficient was less than 0.5. Furthermore, comparison of the values of AVE, ASV, and MSV shows that the AVE values were greater than the values of the other two; each factor had adequate discriminant validity.

\section{Reliability of $B A-M$}

Analysis of each item showed that the values of CITC are greater than 0.3, i.e. greater than the recommended threshold for item validity. Internal consistency indicated at the level sufficient in each factor with the values of 0.782 for the integrated factor and 0.773 for the isolated factor.

\section{DISCUSSION AND CONCLUSION}

We have reported on the development and validation of a scale to measure teachers' beliefs related to mathematics. Three subscales were analyzed separately, including teacher beliefs about the nature of mathematics, mathematics teaching, and assessment in mathematics learning. Based on the results of EFA, each subscale produced two factors. Beliefs about the nature mathematics produced dynamic and relevant factors. The dynamic factor is closely associated with the constructivist perspective of mathematics as a product of human thinking, continuously open for improvement, not a finished product, and having no absolute truth (Ernest, 1991, 1998; Hersh, 1997). Similarly, the relevant factor was also associated with the constructivist view that sees mathematics as an integral part of the nature of human thought, human culture, so it cannot be separated by physical science, nor the other sciences. Therefore, to describe the traditional beliefs about the nature of mathematics using this instrument, the data of one factor can be reversed. Similar scale factor can also be found in Op't Eynde and De 
Corte (2003) who developed the mathematics-related beliefs scale for students. In their study, the beliefs about traditional mathematics are measured by reversing the score obtained by a constructivism factor. Furthermore, beliefs about mathematics teaching and assessment in mathematics learning, each consisting of two factors together, can be associated with the view of constructivism and objectivism (Cooper, 1993; Jonassen, 1991).

Based on the results of the CFA, the suitability criteria for each scale at the limits were adequate. There were nine items of beliefs about the nature of mathematics, 11 items of beliefs of mathematics teaching, and 10 items of beliefs about assessment in mathematics learning. All subscales had adequate construct validity. The alpha coefficients were within $0.715-0.787$, whose factors in each subscale had adequate internal consistency.

There were limitations, including only taking samples from primary school teachers in Jakarta. Therefore, further research needs to take samples from different populations (both in location and school level) to improve the generalization of the findings. In addition, assessed validity of the scales is only convergent and discriminant validity. Therefore, subsequent studies need to consider validity of others, such as divergent validity, predictive, etc.

\section{REFERENCES}

Abdullah, A., Marzbali, M. H., Woolley, H., Bahauddin, A., \& Tilaki, M. J. M. (2014). Territorial functioning and victimisation: conceptualisation and scale development. Crime, Law and Social Change, 61(3), 335-354. https://doi.org/10.1007/s10611-0139490-6

Barkatsas, A. T., \& Malone, J. (2005). A typology of mathematics teachers' beliefs about teaching and learning mathematics and instructional practices. Mathematics Education Research Journal, 17(2), 69-90.

Barrett, P. (2007). Structural equation modelling: Adjudging model fit. Personality and Individual Differences, 42(5), 815-824. https://doi.org/10.1016/j.paid.2006.09.018

Beswick, K. (2005). The beliefs/practice connection in broadly defined contexts. Mathematics Education Research Journal, 17(2), 39-68.

Beswick, K. (2012). Teachers' beliefs about school mathematics and mathematicians' mathematics and their relationship to practice. Educational Studies in Mathematics, 79(1), 127-147. https://doi.org/10.1007/s10649-011-9333-2

Boz, N. (2008). Turkish pre-service Mathematics teachers' beliefs about Mathematics teaching. Australian Journal of Teacher Education, 33(5), 5.

Brown, G. T. L. (2004). Teachers' conceptions of assessment: Implications for policy and professional development. Assessment in Education: Principles, Policy \& Practice, 11(3), 301-318. https://doi.org/10.1080/0969594042000304609 
Brown, G. T. L., \& Gao, L. (2015). Chinese teachers' conceptions of assessment for and of learning: Six competing and complementary purposes. Cogent Education, 2(1), 993836. https://doi.org/10.1080/2331186X.2014.993836

Brown, G. T. L., Hui, S. K. F., Yu, F. W. M., \& Kennedy, K. J. (2011). Teachers' conceptions of assessment in Chinese contexts: A tripartite model of accountability, improvement, and irrelevance. International Journal of Educational Research, 50(5-6), 307-320. https://doi.org/10.1016/j.ijer.2011.10.003

Brown, G. T. L., \& Remesal, A. (2012). Prospective teachers' conceptions of assessment: a cross-cultural comparison. The Spanish Journal of Psychology, 15(1), 7589. https://doi.org/10.5209/rev_SJOP.2012.v15.n1.37286

Byrne, B. M. (2013). Structural equation modeling with AMOS: Basic concepts, applications, and programming. New York: Routledge.

Charalambous, C., Philippou, G., \& Kyriakides, L. (2002). Towards understanding teachers' philosophical beliefs about Mathematics. In A. Cockburn \& E. Nardi (Eds.), Annual meeting of the international group for the psychology of Mathematics education. Norwich: University of East Anglia.

Clark, L. A., \& Watson, D. (1995). Constructing validity: Basic issues in objective scale development. Psychological Assessment, 7(3), 309-319. https://doi.org/10.1037/10403590.7.3.309

Cooper, P. A. (1993). Paradigm shifts in designed instruction: From behaviorism to cognitivism to constructivism. Educational Technology, 33(5), 12-19.

DeVellis, R. F. (2017). Scale development: Theory and applications (Fourth Edition). SAGE Publication Inc. Thousand Oaks, California: SAGE Publications, Inc.

Drageset, O. G. (2010). The interplay between the beliefs and the knowledge of Mathematics teachers. Mathematics Teacher Education and Development, 12(1), 30 49.

Ernest, P. (1991). The philosophy of mathematics education. London: Routledge Falmer.

Ernest, P. (1998). Social constructivism as a philosophy of mathematics. Albany, New York: Suny Press.

Fichman, M., \& Cummings, J. N. (2003). Multiple Imputation for Missing Data: Making the Most of What You Know. Organizational Research Methods, 6(3), 282-308. https://doi.org/10.1177/1094428103006003002

Furinghetti, F., \& Pehkonen, E. (2002). Rethinking characterizations of beliefs. In G. C. Leder, E. Pehkonen, \& G. Törner (Eds.), Beliefs: A hidden variable in mathematics education? (Vols. 31, 39-57). Dordrecht, The Netherlands: Kluwer Academic Publishers. 
Genc, E. (2005). Development and validation of an instrument to evaluate science teachers' assessment beliefs and practices. Department of Middle and Secondary Education. Florida State University, Tallahassee, FL. Retrieved from http://diginole.lib.fsu.edu/etd

Hair, J. F. J., Black, W. C., Babin, B. J., \& Anderson, R. E. (2010). Multivariate data analysis (Seventh Edition). Upper Saddle River, NJ: Prentice Hall, Inc.

Hersh, R. (1997). What is mathematics, really? Oxford, New York: Oxford University Press.

Holm, J., \& Kajander, A. (2012). Interconnections of knowledge and beliefs in teaching mathematics. Canadian Journal of Science, Mathematics and Technology Education, 12(1), 7-21.

Jao, L. (2016). Shifting pre-service teachers' beliefs about Mathematics teaching: the contextual situation of a Mathematics methods course. International Journal of Science and Mathematics Education, 1-20. https://doi.org/10.1007/s10763-016-9719-9

Jonassen, D. H. (1991). Objectivism versus constructivism: Do we need a new philosophical paradigm? Educational Technology Research and Development, 39(3), 514.

Kajander, A. (2007). Unpacking mathematics for teaching: A study of preservice elementary teachers' evolving mathematical understandings and beliefs. Journal of Teaching and Learning, 5(1), 33-54.

Leder, G. C., \& Forgasz, H. J. (2002). Measuring mathematical beliefs and their impact on the learning of mathematics. In G. C. Leder, E. Pehkonen, \& G. Törner (Eds.), Beliefs: A hidden variable in mathematics education (Vol. 31, 95-114). Dordrecht, The Netherlands: Kluwer Academic Publishers.

Loehlin, J. C. (2004). Latent variable models: An introduction to factor, path, and structural analysis (4th edition). Mahwah, N. J.: Psychology Press.

Lui, A. M., \& Bonner, S. M. (2016). Preservice and inservice teachers' knowledge, beliefs, and instructional planning in primary school mathematics. Teaching and Teacher Education, 56, 1-13. https://doi.org/10.1016/j.tate.2016.01.015

Malhotra, N. K., \& Dash, S. (2011). Marketing research: An applied orientation (6th ed.). New Jersey: Pearson Education.

McMillan, J. H., \& Schumacher, S. (2006). Research in education: evidence-based inquiry (6th ed.). Boston: Pearson/Allyn and Bacon.

Nevitt, J., \& Hancock, G. R. (2001). Performance of bootstrapping approaches to model test statistics and parameter standard error estimation in structural equation modeling. $\begin{array}{llll}\text { Structural } \quad \text { Equation } & \text { Modeling, } & \text { 353-377. }\end{array}$ https://doi.org/10.1207/S15328007SEM0803_2 
Op't Eynde, P., \& De Corte, E. (2003). Students' Mathematics-related belief systems: Design and analysis of a questionnaire. In Annual Meeting of the American Educational Research Association. Chicago, IL.

Pellegrino, J. W., Chudowsky, N., \& Glaser, R. (2001). Knowing what students know: the science and design of educational assessment. Washington D. C: National Academy.

Perkkilä, P. (2003). Primary school teachers' mathematics beliefs and teaching practices. In M. A. Mariotti (Ed.), Proceedings of the Third Conference of the European Society for Research in Mathematics Education (pp. 1-8). Bellaria, Italy. Retrieved from http://www.dm.unipi.it/ didattica/CERME3/proceedings/Groups/TG2/TG2_perkkila_cerme3.pdf

Pituch, K. A., \& Stevens, J. P. (2016). Applied multivariate statistics for the social sciences (Sixth Edition). London, United Kingdom: Taylor \& Francis Ltd.

Purnomo, Y. W. (2015). Pengembangan desain pembelajaran berbasis penilaian dalam pembelajaran matematika. Cakrawala Pendidikan, XXXIV(2), 182-191.

Purnomo, Y. W. (2016). Perbaikan Instruksional dalam Implementasi AssessmentBased Learning di Kelas Matematika. Cakrawala Pendidikan, XXXV(3), 403-411. Retrieved from http://journal.uny.ac.id/index.php/cp/article/view/8821

Purnomo, Y. W., Kowiyah, Alyani, F., \& Assiti, S. S. (2014). Assessing number sense performance of Indonesian elementary school students. International Education Studies, 7(8), 74-84. https://doi.org/10.5539/ies.v7n8p74

Purnomo, Y. W., Suryadi, D., \& Darwis, S. (2016). Examining pre-service elementary school teacher beliefs and instructional practices in mathematics class. International Electronic Journal of Elementary Education, 8(4), 629-642.

Savion, L. (2009). Clinging to discredited beliefs: the larger cognitive story. Journal of the Scholarship of Teaching and Learning, 9(1), 81-92.

Schlomer, G. L., Bauman, S., \& Card, N. A. (2010). Best practices for missing data management in counseling psychology. Journal of Counseling Psychology, 57(1), 1-10. https://doi.org/10.1037/a0018082.

Shepard, L. A. (2000). The role of assessment in a learning culture. Educational Researcher, 29(7), 4-14. https://doi.org/10.3102/0013189X029007004

Shinde, M. B., \& Karekatti, T. K. (2012). Pre-service teachers' beliefs about teaching English to primary school children. International Journal of Instruction, 5(1), 69-86.

Suci, V. W., \& Purnomo, Y. W. (2016). Hubungan antara konsepsi penilaian dan kecemasan siswa sekolah dasar di kelas Matematika. Beta, 9(1), 48-60. Retrieved from http://ejurnal.iainmataram.ac.id/index.php/beta

Tabachnick, B. G., \& Fidell, L. S. (2007). Using multivariate statistics (Fifth Edition). Boston, MA: Pearson Education, Inc. https://doi.org/10.1037/022267 
Tatto, M. T., Schwille, J., Senk, S. L., Ingvarson, L., Peck, R., \& Rowley, G. (2008). Teacher education study in mathematics (TEDS-M), conceptual framework. East Lansing, MI: Teacher Education and Development International Study Center, College of Education, Michigan State University.

Thompson, A. G. (1992). Teachers' beliefs and conceptions: A synthesis of the research. In D. A. Grouws (Ed.), Handbook of research on mathematics teaching and learning (pp. 127-146). New York: Macmillan Publishing Co, Inc. Retrieved from http://psycnet.apa.org/psycinfo/1992-97586-007

Van Zoest, L. R., Jones, G. A., \& Thornton, C. A. (1994). Beliefs about mathematics teaching held by pre-service teachers involved in a first grade mentorship program. Mathematics Education Research Journal, 6(1), 37-55. https://doi.org/10.1007/BF03217261

Wilkins, J. L. M. (2008). The relationship among elementary teachers' content knowledge, attitudes, beliefs, and practices. Journal of Mathematics Teacher Education, 11(2), 139-164. https://doi.org/10.1007/s10857-007-9068-2

Worthington, R. L., \& Whittaker, T. A. (2006). Scale development research: A content analysis and recommendations for best practices. The Counseling Psychologist, 34(6), 806-838. https://doi.org/10.1177/0011000006288127

Wymer, W., \& Alves, H. M. B. (2013). Scale development research in nonprofit management \& marketing: a content analysis and recommendation for best practices. International Review on Public and Nonprofit Marketing, 10(1), 65-86. https://doi.org/10.1007/s12208-012-0093-1

\section{Turkish Abstract \\ Öğretmenlerin Matematiğe İlişkin İnançlarını Ölçmeye Yönelik Ölçek Geliştirme: Bir Geçerlik ve Güvenirlik Çalışması}

$\mathrm{Bu}$ çalışmanın amacı öğretmenlerin matematiğe ilişkin fikirleriyle ilgili özellikle matematiğin doğasına olan inançları, matematik öğretimi ve matematikte öğrenmeyi değerlendirmede kullanılması için geçerli bir inanç ölçeği geliştirmektir. Bunu başarmak için ölçek geliştirme çalışması yapılmıştır. 54 maddeden oluşan taslak ölçeğin 16 maddesi matematiğin doğasına olan inançlarla; 23 maddesi matematik öğretimiyle ve 15 maddesi matematikte öğrenmeyi değerlendirmeye ilişkin inançlarla ilgilidir. İlk aşamaya 252 ilkokul öğretmeni katılmış ve ölçek faktörünün yapısını değerlendirmek için açımlayıcı faktör analizi (EFA) uygulanmıştır. İkinci aşamaya, 350 ilkokul öğretmeni katılmış ve açımlayıcı faktör analizinin (EFA) sonuçlarını onaylamak için doğrulayıcı faktör analizi (CFA) uygualnmıştır. Doğrulayıcı faktör analizi sonuçları kurulan modelin nitelikli uyum indekslerine sahip olduğunu göstermiştir.

Anahtar Kelimeler: matematiğe ilişkin inançlar, ilkokul öğretmenleri, ölçek geliştirmek, geçerlilik çalı̧̧maları 


\section{French Abstract}

Une Échelle pour Mesurer les Croyances Concernant les mathématiques de Professeurs : une Validité et une Étude de Fiabilité

Le but de cette étude était de développer et valider une échelle de croyances de professeur liées aux mathématiques, à savoir, des croyances de la nature de mathématiques, l'enseignement de mathématiques et l'évaluation dans l'apprentissage de mathématiques. Une étude de développement d'échelle a été utilisée pour le réaliser. Le projet(contingent) de l'échelle a consisté en 54 articles dans lequel 16 articles liés aux croyances de la nature de mathématiques, 23 articles liés aux croyances de l'enseignement de mathématiques et 15 articles liés aux croyances de l'évaluation dans l'apprentissage de mathématiques. À la première phase, 252 instituteurs ont participé et l'analyse de facteur exploratoire (EFA) a été exécutée pour évaluer la structure du facteur d'échelle. Il y avait deux facteurs à chaque échelle a résulté de l'analyse. À la deuxième phase, 350 instituteurs ont participé et l'analyse de facteur confirmative (CFA) a été exécutée pour confirmer que les facteurs ont résulté de l'EFA. Le résultat de CFA a indiqué que le modèle établi avait des indices convenables suffisants.

Mots Clés: les croyances concernant les mathématiques, les instituteurs, pèsent le développement, des études de validation

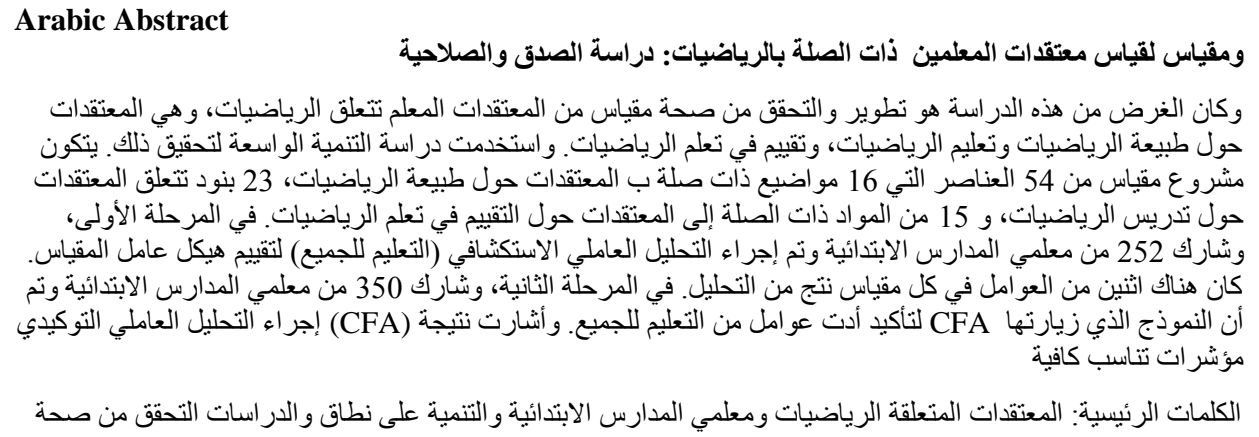

\section{German Abstract}

Eine Skala für die Messung der Mathematik-bezogenen Glauben der Lehrer: Eine Gültigkeits- und Zuverlässigkeitsstudie

Der Zweck dieser Studie war es, eine Skala von Lehrer Glauben in Bezug auf Mathematik zu entwickeln und zu validieren, nämlich Glauben über die Natur der Mathematik, Mathematik Lehre und Bewertung des Mathematiklernens. Eine Skalenentwicklungsstudie wurde verwendet, um es zu erreichen. Die Entwürfe Skala bestand aus 54 Posten, in denen 16 Elemente im Zusammenhang mit Glauben über die Natur der Mathematik, 23 Elemente im Zusammenhang mit Überzeugungen über die Lehre der Mathematik und 15 Elemente im Zusammenhang mit Überzeugungen über die Beurteilung in des Mathematiklernens. In der ersten Phase nahmen 252 Grundschullehrer teil und die Explorationsfaktoranalyse (EFA) wurde durchgeführt, um die Struktur des Skalenfaktors zu bewerten. Es gab zwei Faktoren in jeder Skala, die aus der Analyse resultierten. In der zweiten Phase nahmen 350 Grundschullehrer teil und die Bestätigungsfaktoranalyse (CFA) wurde durchgeführt, um die aus der EFA resultierenden 
Faktoren zu bestätigen. Das Ergebnis von CFA zeigte an, dass das etablierte Modell ausreichend passende Indizes hatte.

Schlüsselwörter: mathematik-bezogene überzeugungen, grundschullehrer, skalenentwicklung, validierungsstudien

\section{Malaysian Abstract \\ Skala untuk Mengukur Guru Matematik Berkaitan Kepercayaan : Kesahan dan Kebolehpercayaan Kajian}

Tujuan kajian ini adalah untuk membangunkan dan mengesahkan skala kepercayaan guru berkaitan dengan matematik, iaitu kepercayaan tentang sifat matematik, pengajaran matematik, dan penilaian dalam pembelajaran matematik. Satu kajian pembangunan skala digunakan untuk mencapainya. Draf skala terdiri daripada 54 item di mana 16 item yang berkaitan dengan kepercayaan tentang sifat matematik, 23 item yang berkaitan dengan kepercayaan tentang pengajaran matematik, dan 15 item yang berkaitan dengan kepercayaan tentang penilaian dalam pembelajaran matematik. Pada fasa pertama, 252 guru sekolah rendah. telah mengambil bahagian dan analisis faktor penerokaan (EFA) dilakukan untuk menilai struktur faktor skala. Terdapat dua faktor pada setiap skala hasil daripada analisis. Pada fasa kedua, 350 guru sekolah rendah telah mengambil bahagian dan analisis faktor pengesahan (CFA) yang dilakukan untuk mengesahkan faktor hasil daripada EFA. Hasil CFA menunjukkan bahawa model yang ditubuhkan mempunyai indeks patut mencukupi.

Kata Kunci: kepercayaan yang berkaitan dengan matematik-guru sekolah rendah, pembangunan skala, kajian pengesahan

\section{Russian Abstract \\ Шкала для Измерения Математика, Связанные с Убеждением Учителя: Валидность и Надежность Исследование}

Цель данного исследования состояла в том, чтобы разработать и утвердить шкалу учительских убеждений, связанных с математикой, а именно, убеждений о природе математики, изучение математики и оценки в процессе обучения. Исследование развития масштаба было использовано для достижения этой цели. Проект “шкала" состоял из 54 пунктов в которых 16 пунктов связанны с убеждениями о природе математики, 23 пункта связанны с преподаванием математики и 15 с оценками в процессе обучения математике. На первом этапе 252 учителя начальной школы принимали участие в поисковом факторном анализе (EFA). Анализ проводился для оценки структуры масштабного коэффициента. В результате анализа были получены два фактора в каждом масштабе. На втором этапе 350 учителей начальной школы принимали участие в подтверждающем факторном анализе (CFA). Анализ был выполнен для подтверждения поискового факторного анализа (EFA). Результат подтверждающего факторного анализа (CFA) показал, что установленная модель имела достаточные показатели подгонки.

Ключевые Слова: математика связанная с убежденим, учителей начальной школы, разработка шкалы, исследования по валидации 